\title{
The abundance and diversity of grasshopper communities in relation to elevation and land use in Malang, Indonesia
}

\author{
AMIN SETYO LEKSONO ${ }^{1, \vartheta}$, BAGYO YANUWIADI ${ }^{1}$, AMINUDIN AFANDHI ${ }^{2}$, MOHAMMAD FARHAN ${ }^{1}$, \\ ANISA ZAIRINA ${ }^{3}$ \\ ${ }^{1}$ Department of Biology, Faculty of Mathematics and Natural Sciences, Universitas Brawijaya. Jl. Veteran, Malang 65145, East Java, Indonesia. \\ Tel./fax.: +62-341-551611, `email: amin28@ub.ac.id \\ ${ }^{2}$ Faculty of Agriculture, Universitas Brawijaya. Jl. Veteran, Malang 65145, East Java, Indonesia \\ ${ }^{3}$ Program of Forestry, Faculty of Forestry, Institut Pertanian Malang. Jl. Soekarno-Hatta, Malang 65141, East Java, Indonesia
}

Manuscript received: 27 August 2020. Revision accepted: 7 November 2020.

\begin{abstract}
Leksono AS, Yanuwiadi B, Afandhi A, Farhan M, Zairina A. 2020. The abundance and diversity of grasshopper communities in relation to elevation and land use in Malang, Indonesia. Biodiversitas 21: 5614-5620. Ecological factors include interactions of the community members with numerous biotic and abiotic factors such as temperature, humidity, precipitation, light intensity, and seasonality show an altitudinal gradient. Most grasshopper species play a role as herbivores and are a good source of protein for other animals such as amphibians, small reptiles, birds, and small mammals. This study aimed to analyze variations in the abundance, richness, and diversity of grasshopper species along an altitudinal gradient. This research was conducted in five locations in Malang District, East Java, Indonesia, namely Bantur, Sumber Pujung Lawang, Pujon, and Poncokusumo. Grasshopper sampling was carried out by the sweeping method using an insect net. Sweepings were carried out on four plots with each plot size of $2 \times 10 \mathrm{~m}^{2}$. Sampling was conducted four times from June to August 2020. The data were analyzed using the Shannon Wiener index (diversity analysis) and the Bray-Curtis index. The differences between locations were tested by one-way analysis of variance. Land use was analyzed by ArcGIS, using Landsat imagery 8. The abundance of grasshoppers had a significant negative correlation with elevation. That correlation was positive to species richness and diversity of grasshoppers. That with species diversity was significant, while that with species richness was not significant. The greatest abundance of the grasshopper was found in the middle elevation in Lawang (19.39 \pm 2.12 ). In contrast, the highest species richness and diversity were found in the highest elevation in Poncokusumo (richness $=15.75 \pm 1.60$ and $\mathrm{H} '=2.58 \pm$ 0.11). Land use variation was not significant on abundance, species, richness, and diversity of grasshoppers. Interestingly, the high similarity of the grasshopper compositions in low elevation habitats was detected, indicating that land use in the low land area was remarkable. The abundance of grasshopper had a significant positive correlation with temperature but negatively correlated with humidity. There was no significant correlation among species richness, species diversity with temperature and humidity.
\end{abstract}

Keywords: Diversity, elevation, Malang District, Orthoptera

\section{INTRODUCTION}

Grasshoppers belong to the order Orthoptera and family Acrididae and are part of the biotic components with an important role in the ecosystem (Culliney 2013). Most grasshopper species play a role in the herbivory process in the ecosystem and are known to be a good source of protein for other animals such as amphibians, small reptiles, birds, and small mammals; therefore, their scarcity may hinder the trophic structure in an ecosystem (Soliman et al. 2017). Grasshoppers are also an important bioindicator because of their specific habitat preferences and sensitivity to any changes in their habitat (Fartmann et al. 2012; Adu-Acheampong et al. 2016; Terra et al. 2017; Löffler et al. 2019). Of the insect group, apart from ants and butterflies, the orthoptera group includes grasshoppers, suitable for use as indicators in open habitats. Studies have shown that grasshoppers can exhibit changes in landscape quality. The number of grasshopper species in the grasslands increases with habitat heterogeneity, which is interrelated with patch size (Schirmel et al. 2010).
At the habitat level, the species richness and abundance of Orthoptera are driven by land use and the vegetation structure, and the influence of abiotic factors. Therefore, conservation management of the Orthoptera should primarily focus on increasing habitat heterogeneity and habitat quality in patches (Löffler and Fartmann 2017). Some grasshoppers act as herbivores on cultivated land so that they have the potential to become pests, for example, the locust.

The grasshopper community is greatly influenced by human activities, both in grassland and forest (van Klink et al. 2015; Ngoute et al. 2020). Agricultural livestock practices have intensified, culminating in the year 2000 in $26 \%$ of the terrestrial biome being used for livestock production as pasture or fodder crops (Gerber et al. 2010). This may pose a threat to grasshopper diversity through overgrazing, plowing, and habitat loss and fragmentation (Fahrig 2003; Latchininsky et al. 2011). Grazing thus has a large impact on a global scale due to agricultural intensification (increased stocking rates), agricultural 
abandonment, and changes in wild herbivore assemblages (Donlan et al. 2006). However, species responses to landscape fragmentation are difficult to predict because they are highly dependent on dispersal capacity and the propensity to traverse inappropriate habitat patches (Blanchet et al. 2010; DiLeo et al. 2010; Lange et al. 2010).

There have been many studies on aspects of grasshopper diversity and abundance (Sirin et al. 2010; Adu-Acheampong et al. 2016; Prakoso 2017). Other studies have evaluated the distribution of orthoptera in relation to elevation (Sirin 2010; Mol and Zeybekoglu 2013). Generally, orthoptera is able to occupy a variety of habitats from low elevations to mountainous regions. Several species belonging to subfamily Gomphocerinae were collected in Black Sea Regions under three distribution range between 200 and 2460 meters above sea level in 175 different localities in Black Sea Regions (Mol and Zeybekoglu 2013). However, none of these studies did the map and specifically test the relationship between grasshopper abundance and diversity with abiotic factors and land-use diversity. This study aims to analyze variations in the abundance, richness, and diversity of grasshopper species at along an altitudinal gradient.

\section{MATERIALS AND METHODS}

\section{Study area}

This research was conducted in five study sites (Bantur, Sumberpucung, Lawang, Pujon, and Poncokusumo) in Malang District, East Java, Indonesia (Figure 1). Each site consisted of four plots. Sampling was conducted four times in the morning (07.00-10.00), June-August 2020 (represent the dry season). Grasshopper sampling was carried out by the sweeping method using insect nets on the grasslands with a plot size of $2 \times 10 \mathrm{~m}^{2}$. Obtained grasshoppers were put infilled a bottle containing $70 \%$ ethanol. The process of grasshopper specimens identifying was carried out at the Laboratory of Animal Diversity, Department of Biology, Faculty of Mathematics and Natural Sciences, Brawijaya University. The specimens were sorted, dried, and then pinned, prior to species-level identification. Small specimens were kept in alcohol, while the big ones were stored in an insectarium. Grasshopper specimen were identified based on Borror et al. (1989) supported with other studies such as Willemse (1930, 1965, 2001), Kalshoven (1981), Rentz (1991), Johnson (2008), and Tan (2012; 2017). Aerial abiotic data (temperature and humidity) were recorded during each sampling event using a digital Digital Thermohygrometer (XON MED ${ }^{\mathrm{TM}}$ HTC2), while light intensity was recorded using a Digital Lightmeter (Krisbow ${ }^{\mathrm{TM}}$ ).

The data was analyzed using the Shannon Wiener index (diversity analysis), and the Bray-Curtis index. The differences between locations were tested by one-way analysis of variance. Land use was analyzed by ArcGIS, using Landsat imagery 8 . The analysis was carried out on a circular area with a diameter of $1 \mathrm{~km}$ with land use criteria referring to the Indonesia National Standard. The relationship between abundance, diversity with abiotic environmental factors, and land use was analyzed with the Pearson correlation. Statistical tests were performed using Excel and SPSS ${ }^{\circ}$ version 20 (SPSS Inc. Chicago, IL, USA).

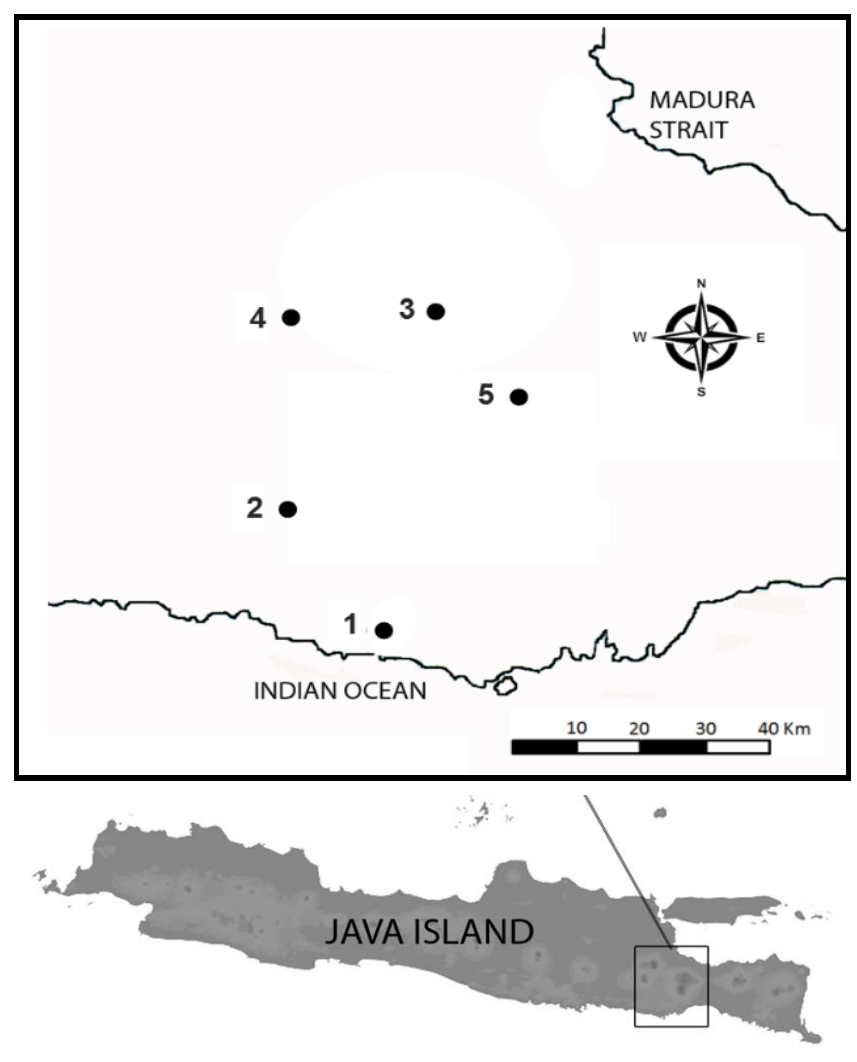

Figure 1. Location of five study sites in Malang District, East Java, Indonesia. 1. Bantur; 2. Sumberpucung; 3. Lawang; 4. Pujon; 5. Poncokusumo. (Modified from Leksono et al. 2017)

\section{RESULTS AND DISCUSSION}

\section{Results}

This study obtained 1,810 individual grasshoppers belonging to 30 species and three families. The most dominant species was Alloteratura sp. (24.36\%), followed by Phlaeoba fumosa (13.43\%), Atractomorpha crenulata (10.17\%), Oxya japonica (8.29\%), and Acrida turrita $(7.85 \%)$ (Table 1). On the other hand, $23.3 \%$ of the collected species has narrow distribution (exist in only one location). These consisted of Acromantis gestri, Ambivia undata, Oxya chinensis, Tagasta marjinella, Traulia azureipennis, Trilophida annulate, and Xenocatantops humilis (Table S1). The distribution of species showed a cluster pattern at certain locations. Alloteratura sp., Oxya japonica, Apalacris varicornis tend to occupy low to moderate elevation habitats, whereas Acrida turrita tends to be abundant in medium elevation habitats. The distribution was categorized as local when the spatial distribution ranges from 1-10 km (Hortal et al. 2010). 
Table 1. Number of individual dominant grasshopper species among five study sites

\begin{tabular}{|c|c|c|c|c|c|c|c|}
\hline Species & Bnt & Sbp & Lwn & Pjn & Pnc & Total & $\%$ \\
\hline Alloteratura sp. $(* * *)$ & 152 & 134 & 155 & 0 & 0 & 441 & 24.36 \\
\hline Phlaeoba fumosa (ns) & 78 & 53 & 46 & 39 & 27 & 243 & 13.43 \\
\hline Atractomorpha crenulata (ns) & 24 & 38 & 63 & 35 & 24 & 184 & 10.17 \\
\hline Oxya japonica $(* *)$ & 67 & 30 & 32 & 0 & 21 & 150 & 8.29 \\
\hline Acrida turrita $(* *)$ & 26 & 13 & 40 & 63 & 0 & 142 & 7.85 \\
\hline Pseudoxya diminuta $(\mathrm{ns})$ & 4 & 0 & 17 & 20 & 35 & 76 & 4.20 \\
\hline Apalacris varicornis $(*)$ & 30 & 24 & 4 & 0 & 11 & 69 & 3.81 \\
\hline Chorthippus biguttulus (ns) & 0 & 0 & 18 & 21 & 11 & 50 & 2.76 \\
\hline Asiophlugis thaumasia (ns) & 0 & 14 & 8 & 17 & 10 & 49 & 2.71 \\
\hline Miscellanies & 48 & 92 & 63 & 41 & 162 & 406 & 22.43 \\
\hline Total & 429 & 398 & 446 & 236 & 301 & 1810 & 100 \\
\hline
\end{tabular}

Note: Bnt: Bantur; Sbp: Sumberpucung; Lwn: Lawang; Pjn: Pujon; Pnc: Poncokusumo; code inside parenthesis $\left(^{*}=\mathrm{p}<0.05\right.$, ** $=\mathrm{p}$ $<0.01, * * *=\mathrm{p}<0.001 \mathrm{~ns}=$ not significant $)$.

Table S1. List of species and its total abundance

\begin{tabular}{lllllll}
\hline Species & Bnt & Sbp & Lwn & Pjn & Pnc & Total \\
\hline Alloteratura sp. & 152 & 134 & 155 & 0 & 0 & 441 \\
Phlaeoba fumosa & 78 & 53 & 46 & 39 & 27 & 243 \\
Atractomorpha crenulata & 24 & 38 & 63 & 35 & 24 & 184 \\
Oxya japonica & 67 & 30 & 32 & 0 & 21 & 150 \\
Acrida turrita & 26 & 13 & 40 & 63 & 0 & 142 \\
Pseudoxya diminuta & 4 & 0 & 17 & 20 & 35 & 76 \\
Apalacris varicornis & 30 & 24 & 4 & 0 & 11 & 69 \\
Stenocatantops angustifrons & 0 & 0 & 18 & 21 & 11 & 50 \\
Asiophlugis thaumasia & 0 & 14 & 8 & 17 & 10 & 49 \\
Gesonula mundata & 9 & 0 & 17 & 0 & 22 & 48 \\
Valanga nignicornis & 14 & 12 & 15 & 0 & 7 & 48 \\
Phlaeoba infumata & 15 & 18 & 4 & 0 & 10 & 47 \\
Conocephalus fasciatus & 0 & 0 & 9 & 20 & 7 & 36 \\
Oxya chinensis & 0 & 28 & 0 & 0 & 0 & 28 \\
Tenodera australasiae & 0 & 11 & 0 & 0 & 13 & 24 \\
Sedulia specularia & 0 & 0 & 0 & 7 & 16 & 23 \\
Ceratocrania macra & 0 & 0 & 3 & 6 & 13 & 22 \\
Euconocephalus varius & 0 & 4 & 10 & 0 & 7 & 21 \\
Xenocatantops humilis & 0 & 0 & 0 & 0 & 20 & 20 \\
Traulia azureipennis & 0 & 0 & 0 & 0 & 15 & 15 \\
Trilophida annulata & 0 & 0 & 0 & 0 & 14 & 14 \\
Locusta sp. & 0 & 8 & 5 & 0 & 0 & 13 \\
Hierodula patellifera & 4 & 6 & 0 & 0 & 2 & 12 \\
Pteronemobius sp. & 0 & 0 & 0 & 4 & 7 & 11 \\
Locusta migratoria & 5 & 5 & 0 & 0 & 0 & 10 \\
Hierodula vitrea & 0 & 0 & 0 & 3 & 2 & 5 \\
Statilia maculata & 0 & 0 & 0 & 1 & 3 & 4 \\
Anchiale briareus & 0 & 0 & 0 & 0 & 2 & 2 \\
Tagasta marginella & 0 & 0 & 0 & 0 & 2 & 2 \\
Acromantis gestri & 1 & 0 & 0 & 0 & 0 & 1 \\
Grand Total & 429 & 398 & 446 & 236 & 301 & 1810 \\
\hline & & & & & &
\end{tabular}

\section{Land use variability surrounding the study sites}

Landscape analysis showed that Bantur was dominated by paddy field $(69.7 \%)$ and pasture land $(15 \%)$. That in Sumberpucung was dominated by paddy fields $(83 \%)$. Lawang was dominated by residential areas (35\%), paddy field $(22.4 \%)$, and cropland (22.2\%). Habitat in Pujon was dominated by vegetable cropland $(75.8 \%)$, while Poncokusumo was dominated by orchard (40\%) and forest $(48.11 \%)$ (Table 2).
Table 2. Land uses variation among five study sites

\begin{tabular}{lccccc}
\hline Land uses (\%) & Bnt & Sbp & Lwn & Pjn & Pnc \\
\hline Residential area & 10 & 5.16 & 35 & 3 & 10 \\
Paddy field & 69.7 & 83 & 22.4 & & \\
Crop land & 5 & & 22.2 & 75.8 & 10 \\
Pasture land & 15 & & & & \\
Industrial area & & & 5 & & 30 \\
Orchard & & & 9.55 & 17 & 48.11 \\
Forest or vegetation area & & 10 & 0.46 & 0.32 & 0.19 \\
Waterbody & & 1.2 & 3.83 & 1.53 & 1.2 \\
Traffic area & 0.3 & 0.64 & 1.56 & 2.35 & 0.5 \\
Recreation area & &
\end{tabular}

Note: Bnt: Bantur; Sbp: Sumberpucung; Lwn: Lawang; Pjn: Pujon; Pnc: Poncokusumo

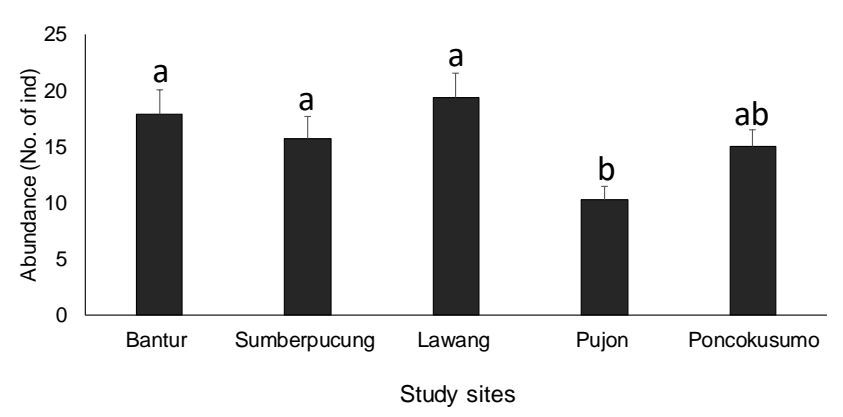

Figure 2. The Abundance variation of grasshopper among five study sites in Malang District, East Java, Indonesia

The abundance, species richness, and diversity across elevation and land use

The abundance of grasshopper varied among study sites. The greatest abundance of the grasshopper was found in Lawang $(19.39 \pm 2.12)$, while the lowest was in Pujon $(10.26 \pm 1.16)$. The highest species richness and diversity were found in Poncokusumo (richness $=15.75 \pm 1.60$ and $\mathrm{H}^{\prime}=2.58 \pm 0.11$ ) (Figures 2 and 3), while the lowest was found in Bantur (richness $=8.25 \pm 0.25$ and $H^{\prime}=1.76 \pm$ 0.09) (Figure 4). 


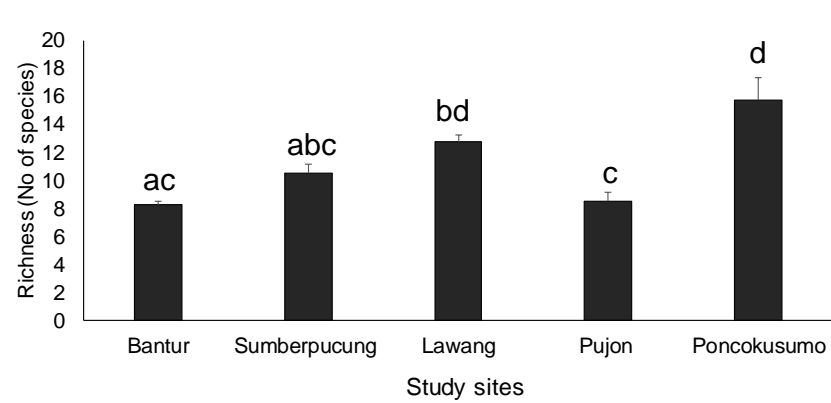

Figure 3. The species richness variation of grasshopper among five study sites in Malang District, East Java, Indonesia

There was a significant negative correlation $(\mathrm{P}<0.001)$ between elevation and abundance. The correlation between elevation with both species' diversity and richness was positive. The correlation between elevation and species diversity was significant $(\mathrm{P}<0.05)$ (Figure 5). The temperature was ranged from $21^{\circ}$ to $30^{\circ} \mathrm{C}$. The overall abundance had a positive correlation with temperature, and the correlation was significant $(\mathrm{P}<0.05)$, while species richness and diversity were vice versa (Figure 6). Humidity was ranged from $60 \%$ to $73 \%$. The overall abundance had a negative correlation with humidity, and the correlation was significant $(\mathrm{P}<0.05)$, while species richness and diversity were vice versa (Figure 7). The correlation among species richness and diversity with temperature and humidity was not significant. The highest mean temperature was in low elevation while the lowest was found in high elevation. There were no significant correlations between land use characteristics and the abundance, species richness, and diversity of the grasshoppers.

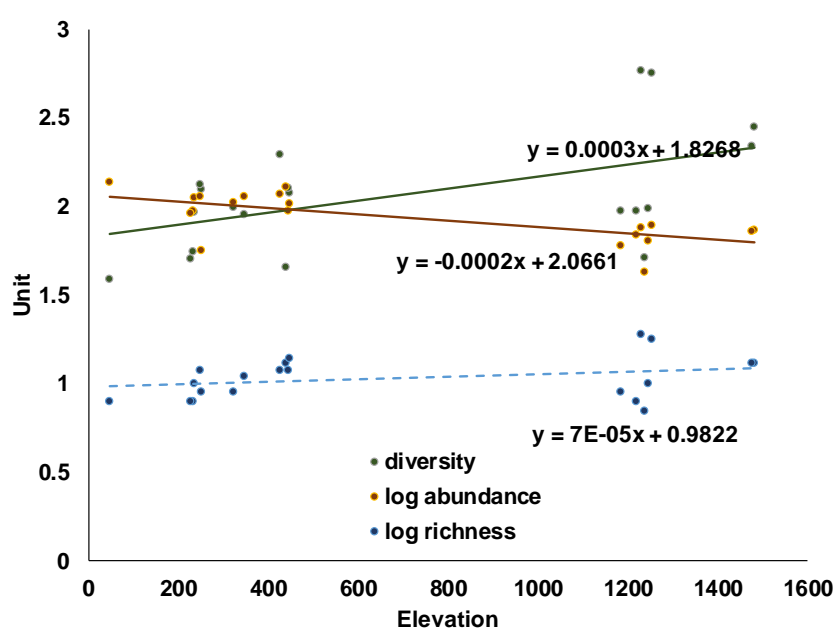

Figure 5. Correlations between elevation and grasshopper abundance, species richness, and species diversity

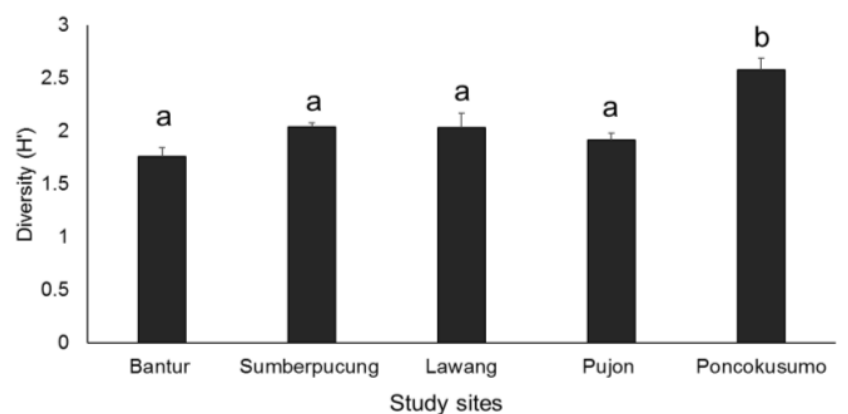

Figure 4. The diversity variation of grasshopper among five study sites in Malang District, East Java, Indonesia

The grasshopper compositions were grouped into two clusters. The first was composed of Bantur, Poncokusumo, and Sumberpucung, and the second consisted of Pujon and Poncokusumo. The grasshopper compositions between Bantur and Sumberpucung were the most similar (75.9\%). Those with a community in Lawang formed the first cluster with a similarity of $71.3 \%$ (Figure 8 .A). This trend showed that the clustering was based on the elevation. This means that the composition of grasshoppers was influenced by the elevation factor. The high similarity of the grasshopper compositions in Bantur and Sumberpucung seems to relate to the land use composition. The land-use composition in Bantur and those in Sumberpucung was the most similar (75.9\%) (Figure 8.B). In addition, the grasshopper compositions and land use composition between study sites were significantly correlated $(\mathrm{P}<0.01)$.

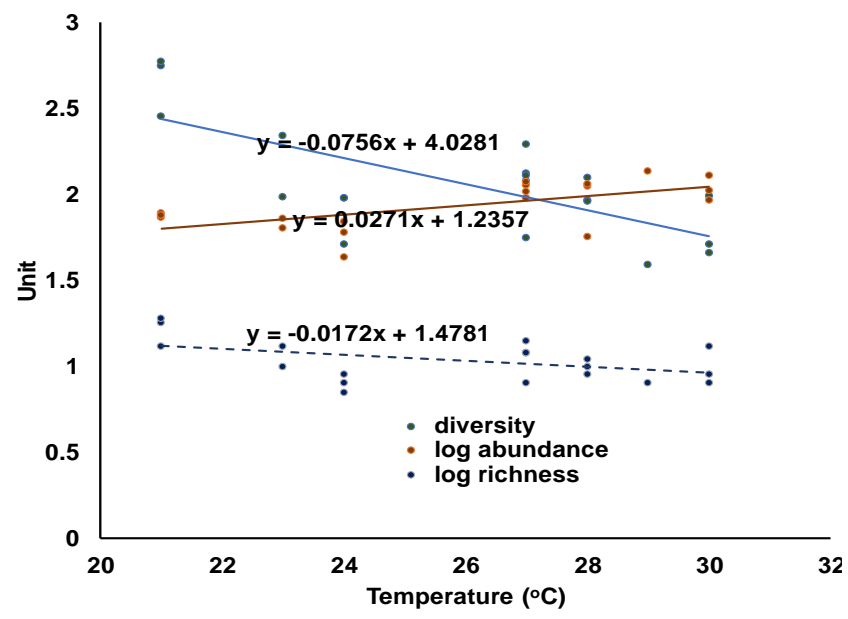

Figure 6. Correlations between temperature and grasshopper abundance, species richness, and species diversity 


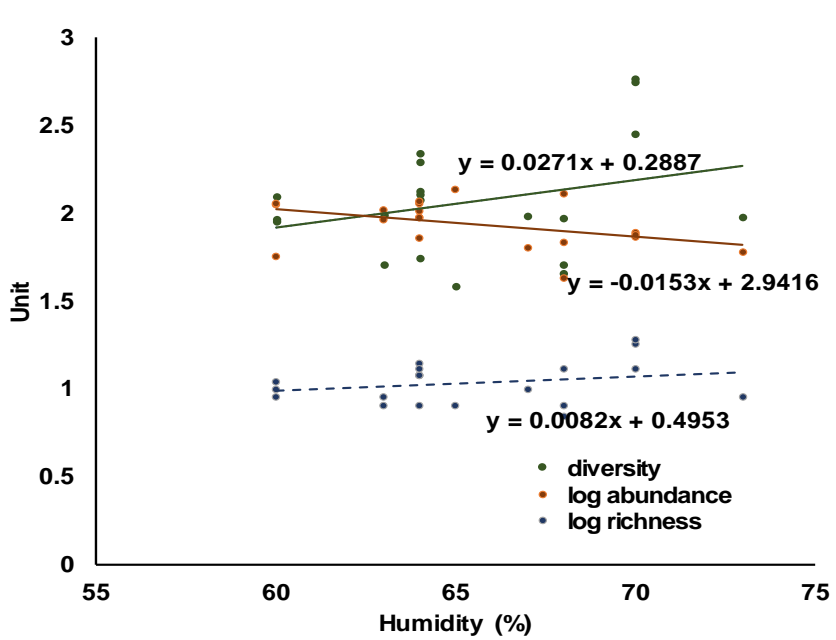

Figure 7. Correlations between humidity and grasshopper abundance, species richness, and species diversity

\section{Discussion}

This study showed that the grasshopper abundance varied among the study sites. This variation is influenced by environmental factors, including elevation, temperature, and humidity. This study indicated that land use had no effect on grasshopper abundance. According to the habitat, nine grasshopper species are common species such as Alloteratura sp., Phlaeoba fumosa, Atractomorpha crenulata, Oxya japonica, and Acrida conica. While, Atractomorpha crenulata, Oxya hyla, and Hesperotettix viridis are species commonly found in maize gardens. Furthermore, Gesonula mundata and Valanga nigricornis are common in plantation forests (Prakoso 2017). This study showed that the highest abundance of grasshoppers is found in middle elevations $(400 \mathrm{~m}$ asl). The results of this study are supported by previous studies which state that species diversity and abundance of grasshoppers is highest in the medium lands and lower in the high and lowlands (Sirin et al. 2010). Differences in altitude, plant composition, steep nature, urbanization and livestock grazing, and latitude positions also contribute to the variation (Sirin et al. 2010).

Many factors can influence grasshopper species diversity, including resource availability, habitat structure, escape space, and predators (Joern 2004; Joern 2005). Five environmental factors, including the number of flower heads, disturbance intensity, altitude, humidity, and the cover of shrubs and trees in the wider plot area, significantly influenced the distribution pattern of the locust community, explaining $32 \%$ of the overall variance. The endemic grasshopper was strongly associated with flower headcount and humidity, whereas it was negatively related to disturbance intensity and shrub and tree cover. Humidity has a regulatory effect on the hatchery of grasshoppers and the seasonality of their life cycle. It is also important for species of conservation concern such as the endangered C. lacustris (Kati et al. 2006). Elevation, flower-heads abundance, low disturbance intensity, and plant species richness predict grasshopper species richness well, while the latter together with humidity predict plant

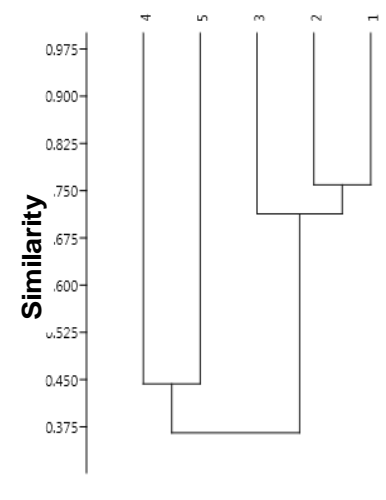

A

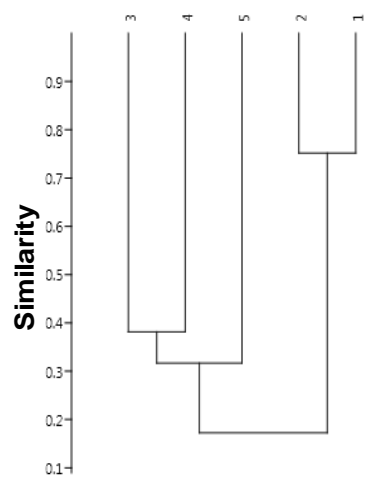

B
Figure 8. The similarity of grasshopper compositions (A) and Land use compositions (B) among study sites. 1. Bantur; 2. Sumberpucung; 3. Lawang; 4. Pujon; 5. Poncokusumo

species richness (Kati et al. 2012). A study on the species composition, diversity, abundance, and density of four rangelands types in China, showed that the greatest abundance of grasshoppers was found in mountain rangeland, while the lowest abundance of grasshoppers was caught in alpine shrublands (Sun et al. 2015).

This study showed that grasshopper abundance had no significant correlation with land use, but the composition had. The paddy fields exist in the lowland, while cropland and forest/vegetation areas exist in the highland. Previous research results indicated that grasshopper communities were not always associated with grassland habitats but also supported by herbaceous shrubs. The existence of this plant group supports the diversity of grasshoppers because it is associated with providing a larger source of food. Shrub and tree cover appears to be an important factor in establishing locust habitat, providing shelter, oviposition, and a source of food for some grasshopper species (Zografou et al. 2009). Many studies have examined the relationship between grasshopper communities' composition and vegetation patterns in grassland ecosystems worldwide (Joern 2005). Plant diversity often has a positive effect on grasshopper species diversity, but the relationship is sometimes inconsistent. In addition, the grasshopper diet can have an important impact on local plant abundance and community structure (Belovsky and Slade 2009). Grasshoppers are often the dominant native herbivores in grassland ecosystems worldwide, with economically devastating locust outbreaks frequently occurring in western North America (Branson et al. 2006).

Nevertheless, a number of significant associations between plant diversity and grasshopper diversity were found through regression analysis. The results were very different between years suggesting that plant species richness and diversity did not lead to a strong influence on grasshopper diversity metrics.

The pattern of variation in environmental factors, abundance, and species richness is also influenced by the relationship with orthopterofauna from adjacent areas (Jarčuška et al. 2019). Furthermore, management practices 
such as livestock grazing and crop species composition are impacted by fire and then influence the species composition of grasshoppers (Joubert et al. 2016; Joern 2004). Plant species richness seems too crude to lead to accurate predictions of grasshopper species richness in this system, which is dominated by generalist grasshopper species (Branson 2010). Across all sites and grazing intensities, grasshopper abundance tended to be the lowest and diversity highest in plant communities with intermediate biomass and plant species richness (Hao et al. 2015).

The abundance and species diversity of grasshoppers varied along with an altitudinal gradient of land uses, while species richness did not differ significantly. Grasshopper compositions in low elevation have shown close similarity. This situation may associate with habitat composition. Temperature and humidity are among the important factor.

\section{ACKNOWLEDGEMENTS}

The authors thank the Rector and Dean of Faculty of Mathematics and Natural Sciences, Universitas Brawijaya, Malang, Indonesia. This research was funded by Professor and Senior Lecture Grant of Universitas Brawijaya.

\section{REFERENCES}

Adu-Acheampong S, Bazelet CS, Samways MJ. 2016. Extent to which an agricultural mosaic supports endemic species-rich grasshopper assemblages in the Cape Floristic Region biodiversity hotspot. Agr Ecosys Environ 227: 52-60.

Belovsky G, Slade J. 2009. An ecosystem perspective on grasshopper control: possible advantages to no treatment. J Orthoptera Res 11 (1): 29-35. $\quad$ DOI: $\quad 10.1665 / 1082-6467(2002) 011[0029$ AEPOGC]2.0.CO;2.

Blanchet S, Rey O, Etienne R, Lek S, Loot G. 2010. Species-specific responses to landscape fragmentation: implications for management strategies. Evol Appl 3: 291-304. DOI: 10.1111/j.17524571.2009.00110.x

Borror DJ, Triplehor N, Johnson NF. 1989. An Introduction to the Study of Insect. 6th ed. Saunders College Publishing, New York.

Branson DH, Joern A, Sword GA. 2006. Sustainable management of insect herbivores in grassland ecosystems: New perspectives in grasshopper control. BioScience 56: 743-755.

Branson DH. 2011. Relationships between plant diversity and grasshopper diversity and abundance in the Little Missouri National Grassland. Psyche: J Entomol 2011: 748635. DOI: 10.1155/2011/748635.

Culliney TW. 2013. Role of arthropods in maintaining soil fertility. Fla Entomol 96: 235-244.

DiLeo MF, Row JR, Lougheed SC. 2010. Discordant patterns of population structure for two co-distributed snake species across a fragmented Ontario landscape. Divers Distrib 16: 571-581.

Donlan JC, Berger J, Bock CE, Bock JH, Burney DA, Estes JA, Foreman D, Martin PS, Roemer GW, Smith FA, Soulé ME, Greene HW. 2006. Pleistocene rewilding: An optimistic agenda for twenty-first-century conservation. Am Nat 168: 660-681.

Fahrig L. 2003. Effects of habitat fragmentation on biodiversity. Annu Rev Ecol Evol Syst 34: 487-515.

Fartmann T, Krämer B, Stelzner F, Poniatowski D. 2012. Orthoptera as ecological indicators for succession in steppe grassland. Ecol Indic 20. 337-344. 10.1016/j.ecolind.2012.03.002.

Gerber P, Harold A, Mooney HA, Dijkman J, Tarawali S, de Haan C. 2010. Livestock in a changing landscape: Experiences and regional perspectives. Volume 2. Island Press, Washington, D.C.

Hao S, Wang S, Cease A, Kang 1. 2015. Landscape-level patterns of grasshopper communities in Inner Mongolia: Interactive effects of livestock grazing and a precipitation gradient. Landsc Ecol 30: 16571668. DOI: 10.1007/s10980-015-0247-8

Hortal J, Roura-Pascual N, Sanders NJ, Rahbek C. 2010. Understanding (insect) species distributions across spatial scales. Ecography 33: 5153.

Jarčuška B, Kaňuch P, Nad'o L, Krištín A. 2019. Quantitative biogeography of Orthoptera does not support classical qualitative regionalization of the Carpathian Mountains. Biol J Linn Soc 128: 887-900. DOI: 10.1093/biolinnean/blz143

Joern A. 2004. Variation in grasshopper (Acrididae) densities in response to fire frequency and bison grazing in tallgrass prairie. Environ Entomol 33(6): 1617-1625.

Joern A. 2005. Disturbance by fire frequency and bison grazing modulate grasshopper assemblages in tallgrass prairie. Ecology 86: 861-873.

Johnson DL. 2008. Grasshopper Identification and Control Methods to Protect Crops and the Environment. Pulse Canada and Saskatchewan Agriculture and Food, Canada.

Joubert L, Pryke JS, Samways MJ. 2016. Positive effects of burning and cattle grazing on grasshopper diversity. Insect Conserv Divers 9: 290301. DOI: 10.1111 icad.12166

Kalshoven LGE. 1981. Pests of Crops in Indonesia. Laan PA van der (trans.). PT. Ichtiar Baru van Hoeve, Jakarta.

Kati V, Mani P, von Helversen O, Willemse F, Elsner N, Dimopoulos P. 2006. Human land-use threatens endemic wetland species: the case of Chorthippus lacustris (La Greca and Messina 1975) (Orthoptera: Acrididae) in Epirus, Greece. J Insect Conserv 10: 65-74.

Kati V, Zografou K, Tzirkalli E, Chitos T, Willemse L. 2012. Butterfly and grasshopper diversity patterns in humid Mediterranean grasslands: the roles of disturbance and environmental factors. J Insect Conserv 16: 807-818. DOI: 10.1007/s10841-012-9467-2

Lange R, Durka W, Holzhauer SIJ, Wolters V. Diekotter T. 2010. Differential threshold effects of habitat fragmentation on gene flow in two widespread species of bush crickets. Mol Ecol 19: 4936-4948.

Latchininsky A, Sword GA, Sergeev MG, Cigliano MM, Lecoq M. 2011. Locusts and grasshoppers: Behavior, ecology and biogeography. Psyche 2011: 578327. DOI: 10.1155/2011/578327.

Leksono AS, Feriwibisono B, Arifianto T, Pratama AF. 2017. The abundance and diversity of Odonata along an altitudinal gradient in East Java, Indonesia. Entomol Res 47: 248-255.

Löffler F, Fartmann T. 2017. Effects of landscape and habitat quality on Orthoptera assemblages of pre-alpine calcareous grasslands. Agric Ecosyst Environ 248: 71-81. DOI: 10.1016./j.agee.2017.07.029

Löffler F, Poniatowski D, Fartmann T. 2019. Orthoptera community shifts in response to land-use and climate change-Lessons from a long-term study across different grassland habitats. Biol Conserv 236: 315-323. DOI: $10.1016 /$ j.biocon.2019.05.058

Mol A, Zeybekoglu U. 2013. Distribution and taxonomy of Gomphocerinae (Orthoptera, Acrididae) species in the Anatolian Black Sea Basin and checklist of Turkey subfamily fauna. J Entomol Res 15 (2): 69-102.

Ngoute C, Sévilor K, Lecoq M, Nzoko A, Aude C, Nyobe U, Bilong Bilong C. 2020. Effect of anthropogenic pressure on grasshopper (Orthoptera: Acridomorpha) species diversity in three forests in southern Cameroon. J Orthoptera Res 29: 25-34. DOI: 10.3897/jor.29.33373.

Prakoso B. 2017. Biodiversitas belalang (Acrididae: ordo Orthoptera) pada agroekosistem (Zea mays L.) dan ekosistem hutan tanaman di Kebun Raya Baturaden, Banyumas. Biosfera 34 (2): 80-88. [Indonesian]

Rentz DCF. 1991. Orthoptera (Grasshoppers, locus, katydids, crickets). In: CSIRO (eds) The Insects of Australia. A Textbook For Students and Research Workers. Volume 2. Melbourne University Press, Carlton.

Schirmel J, Blindow I, Fartmann T. 2010. The importance of habitat mosaics for Orthoptera (Caelifera and Ensifera) in dry heathlands. Eur J Entomol 107: 129-132. DOI: 10.14411/eje.2010.017.

Sirin D, Eren O, Çiplak B. 2010. Grasshopper diversity and abundance in relation to elevation and vegetation from a snapshot in Mediterranean Anatolia: Role of latitudinal position in altitudinal differences. J Nat Hist 44: 1343-1363. DOI: 10.1080/00222930903528214.

Soliman MM, Haggag AA, El-Shazly MM. 2017 Assessment of grasshopper diversity along a pollution gradient in the Al-Tebbin Region, South Cairo, Egypt. J Entomol Zool Stud 5: 298-306.

Sun T, Liu ZY, Qin LP, Long RJ. 2015. Grasshopper (Orthoptera: Acrididae) community composition in the rangeland of the northern 
slopes of the Qilian Mountains in northwestern China. J Insect Sci 15(1): 1-7. DOI: 10.1093/jisesa/ieu 171 .

Tan MK. 2012. Orthoptera in the Bukit Timah and Central Catchment Nature Reserves (Part 1): Suborder Caelifera. Raffles Museum of Biodiversity Research, National University Singapore, Singapore.

Tan MK. 2017. Orthoptera in the Bukit Timah and Central Catchment Nature Reserves (Part 2): Suborder Ensifera. Raffles Museum of Biodiversity Research, National University Singapore, Singapore.

Terra BR, Gatti FD, Carneiro MAA, Costa MKM. 2017. The grasshoppers (Orthoptera: Caelifera) of the grasslands in the southern portion of the Espinhaço Range, Minas Gerais, Brazil. Check List 13: 1-16.

van Klink R, van der Plas F, van Noordwijk CGE, WallisDeVries MF, Olff H. 2015. Effects of large herbivores on grassland arthropod diversity. Biol Rev Camb Philos Soc 90: 347-366. DOI: $10.1111 /$ brv. 12113
Willemse C. 1930. Fauna Sumatrensis (Bijdrage Nr. 62). Preliminary Revision of the Acrididae (Orthoptera). De Nederlandsche Entomiligsche Vereeniding.

Willemse F. 1965. Orthoptera, Acridiidae chiefly from Java in the Zoologisches Staats Institut und Zoologisches Museum of Hamburg Entomologiche Mitteilungen aus dem. Zoologisches Staats institut und Zoologisches Museum, Hamburg 3: 53-67.

Willemse L. 2001. Fauna Malesiana Guide to The Pest Orthoptera of Indomalayana Region. Backhuys Publisher, Leiden.

Zografou K, Sfenthourakis S, Pullin A, Kati V. 2009. On the surrogate value of red-listed butterflies for butterflies and grasshoppers: A case study in Grammos site of Natura 2000, Greece. J Insect Conserv 13: 505-514. DOI: 10.1007/s10841-008-9198-6. 